\title{
Teaching science throughout the six-year medical curriculum: Two-year experience from the University of Split School of Medicine, Split, Croatia
}

\author{
Ana Marušić, Mario Malički, Dario Sambunjak, Ana Jerončić, Matko Marušić
}

Department of Research in Biomedicine and Health, University of Split School of Medicine, Split, Croatia

Corresponding author:

Matko Marušić

Department of Research

in Biomedicine and Health

School of Medicine, University of Split

Šoltanska 2

21000 Split, Croatia

matko.marusic@mefst.hr

Tel.:/Fax.: + 38521557820

Received: 13 August 2013

Accepted: 11 November 2013

Copyright (C) 2014 by

Academy of Sciences and Arts

of Bosnia and Herzegovina.

E-mail for permission to publish:

amabih@anubih.ba
Objective. The aim of this article is to present the introduction of a mandatory, vertically integrated course in research methodology into medical curriculum. At the School of Medicine in Split (Croatia) we organized this course in 2010, with the total of 270 hours in the 6-year curriculum. In the first year (50 hours) students learned basic principles of scientific method, structure of scientific article, basic statistical concepts, data analysis, interpretation and presentation. In the second year (25 hours) students applied the knowledge from the first year in real examples of research data to answer a research hypothesis and present the results and conclusions. Students were guided through the process of making a hypothesis, analyzing data, interpreting them, constructing tables and figures, and writing a short research report. At the end of the course they formally presented the results to other students and course teachers, using PowerPoint slides. The third year (25 hours) was devoted to mastering concepts and basic skills of evidencebased medicine (EBM). The course in the fourth year ( 25 hours) was integrated with the clinical courses (internal medicine, neurology, and psychiatry) and structured as a "journal club". In the fifth year (25 hours), the teaching was devoted to developing a research plan for the graduation thesis that the students had to conduct during the sixth year. The sixth year (120 hours) was devoted to the execution of research planned in the fifth year, including data collection, data analysis, interpretation, and thesis writing and defense. Conclusion. The new course succeeded in increasing students' knowledge and skills for critical thinking and EBM, and prepared them for life-long learning in medicine.

Key words: Medical Education, Evidence-Based Medicine, Medical Research, Teaching Methods.

\section{Introduction}

"The first 2 years of medical school have got to be changed. Students are spending more and more time understanding the difficult aspects of molecular biology, but we are kidding ourselves to think they use their knowledge of DNA - in my day it was the Krebs cycle in making clinical decisions at the bedside. They do not. They make clinical decisions based on how the last patient did, how their friends are treating patients and what the latest article by an authority says they should do. And we have got repeated evidence now that the authorities are way behind with regard to the 
data in clinical trials. In medical school, I think we have to just hammer away at evidence and probability theory and general statistics."

Dr. Thomas Chalmers, American physician who played a pivotal role in the scientific development of the randomized control trial and meta-analysis (1).

There is a growing recognition that the knowledge about research design, conduct and analysis is low in biomedicine, both in developing and developed countries (2-4). In small countries, this lack of knowledge is coupled with serious barriers to conducting research, such as the shortage of researchers who could generate critical mass of sustainable research output, financial restrictions, communication and language barriers (58). Despite strategies proposed to alleviate problems (5-8), research in most small and developing countries lags behind that in countries belonging to the so-called mainstream science (9).

Over the last 20 years, through our work as educators and editors of a general medical journal dedicated to publishing research from small scientific communities (10-12), we have also recognized that researchers from developing countries often lacked adequate training in critical assessment, research methodology and statistics. To address these problems in our own country and prevent them at their core we introduced obligatory science teaching in medical schools in Croatia.

The aim of this article is to present our experience in introducing a mandatory, vertically integrated course in research methodology into medical curriculum.

\section{Science teaching in medical schools in Croatia}

In 1996, to complement the existing courses of medical informatics and statistics, we had introduced a mandatory 25-hour course on research methodology, critical assessment and scientific writing into the curriculum of the University of Zagreb School of Medicine at the second year of a six-year medical program (13). In the following year, the course was accepted by other three medical schools in Croatia. The evaluation of our course in two observational cross-sectional studies, and a cohort study alongside a nonrandomized trial showed a positive effect of the course on the students' knowledge and attitudes toward science (14-17).

In 2010, as part of Croatia's then upcoming ascension to the EU, all schools of medicine had to introduce new medical curriculums and satisfy the European Directive 2005/36/EC, which required that all medical students upon graduation have: "Adequate knowledge of science upon which medicine is based, and good comprehension of scientific methods, including the principles of biological functions and assessment of measuring biological functions, the evaluation of scientifically established facts and the analysis of data" $(18,19)$. Based on our previous experiences, and in line with the World Federation for Medical Education (WMFE) recommendations (20), we were successful in convincing the School of Medicine at the University of Split to introduce a longitudinal six-year mandatory teaching of science (21).

\section{New science education at the School of Medicine in Split}

In designing the program, alongside our previous experience with the second year mandatory course on scientific methodology, we relied on the basic principles of adult learning and the recommendations for designing medical courses (3, 23-33) (Supplementary table 1). We divided a total study load of 270 hours of teaching granted for the course in six smaller parts, and spread them longitudinally throughout the 6 years of an integrated 
Table 1 Overview of the new vertically and horizontally integrated science course at the University of Split School of Medicine

\begin{tabular}{|c|c|c|}
\hline $\begin{array}{l}\text { Curriculum year } \\
\text { (no. of class hours) }\end{array}$ & Teaching topics & Course outcomes \\
\hline $1^{\text {st }}$ year $(50)$ & $\begin{array}{l}\text { - Principles of health research } \\
\text { - Structure of research articles } \\
\text { - Study designs } \\
\text { - Principles of statistics: populations and samples, } \\
\text { types of data, hypothesis testing, sources of } \\
\text { error, data estimation, description, interpretation } \\
\text { and presentation }\end{array}$ & $\begin{array}{l}\text { - Writing of curriculum vitae according to } \\
\text { the EU standard (Europass) } \\
\text { - Writing of research abstract in English } \\
\text { - Series of problem-oriented practicals in } \\
\text { study design and statistics }\end{array}$ \\
\hline $2^{\text {nd }}$ year (25) & $\begin{array}{l}\text { - Short repetition of the first year } \\
\text { - Data analysis and presentation } \\
\text { - Writing research report }\end{array}$ & $\begin{array}{l}\text { - Statistical analysis of a dataset according to } \\
\text { specified research question } \\
\text { - Brief written report on results } \\
\text { - Oral presentation of results to colleagues } \\
\text { and teachers }\end{array}$ \\
\hline $4^{\text {th }}$ year $(25)$ & $\begin{array}{l}\text { "Journal clubs": critical reading of research } \\
\text { papers with different study designs (cross- } \\
\text { sectional, cohort and case-control studies, } \\
\text { randomized controlled trials, systematic } \\
\text { reviews), relevant to clinical rounds }\end{array}$ & $\begin{array}{l}\text { Answering a specific clinical question } \\
\text { student encountered in his/hers clinical } \\
\text { rounds (PICO question, literature search, } \\
\text { critical assessment, decision) }\end{array}$ \\
\hline $5^{\text {th }}$ year $(25)$ & $\begin{array}{l}\text { Writing research proposal for diploma thesis } \\
\text { (structured proposal addressing background } \\
\text { research, research hypothesis, study design, } \\
\text { sample size calculation, participants, ethical } \\
\text { approval, intervention, main outcome measures, } \\
\text { bias and confounding factors, statistical analysis, } \\
\text { authorship and publication plan, financial } \\
\text { support, conflict of interest declaration) }\end{array}$ & $\begin{array}{l}\text { - Written research proposal for diploma (MD) } \\
\text { thesis }\end{array}$ \\
\hline 6th year (120) & $\begin{array}{l}\text { Short repetition of the first five years } \\
\text { Methodological counseling and support during } \\
\text { all stages of research for diploma thesis }\end{array}$ & - Published thesis \\
\hline
\end{tabular}

medical curriculum, with horizontal integration of the topics with other courses at their respective individual curriculum years. Student groups for seminars ranged from 24-28, and for excercises from 11-14 students. Recommended literature encompassed two textbooks, both in Croatian and English $(34,35)$. Each year's main topics, outcomes and their evaluation methods are presented in Table 1 , with a more detailed analysis presented in the following paragraphs.

\section{The First Year}

First year students are always shocked by the extent of material they need to absorb in during medical curriculum, even more so in Europe, as high-school/secondary education is most often followed directly by integrated six-year medical studies (36). Students thus tend to see research education, and "non-medical" courses in general, as an unnecessary burden that takes their precious time away from "more important" courses such as Anatomy, Physiology and Pathology. We have therefore allocated the first year's block, consisting of 50 hours (2 weeks) of teaching, at the very end of the first year. Starting with basic principles of scientific method and reasoning, the structure of scientific article, study designs and literature 
search, students are gradually introduced to the basic statistical concepts, most notably data types, sample and population descriptors, sources of error, statistical tests, data analysis, and finally data interpretation and presentation. Knowledge and skills learned in the first year's block are evaluated through a series of practical tasks; these are marked and constitute $70 \%$ of the final grade, followed by a multiple-choice written test at the end of the course (30\% of the final grade). At first, students were resistant toward any "mathematical" concepts discussed in the class. However, as they realized how these concepts helped explain everyday clinical problems and questions about health, they appreciated the problem solving exercises and became skilled in identifying study designs in published reports in proposing designs to address research questions during practical work.

\section{The Second Year}

The second year's block, consisting of 25 hours (one week) of teaching, was designed as practical application of knowledge from the first year to practical research problems. Students worked in groups of two; each group received a prepared de-individualized Excel database with individual data from a previously conducted research study and were instructed to answer a specific research question based on these data. During the 5 days of the course students were guided through the process of making a hypothesis, analyzing data, interpreting them, constructing tables and figures (minimum of one figure and one table), and writing a short research report. At the end of the course they formally presented the results to other students and course teachers, using PowerPoint slides. The course mark was based on the quality of their final research report and presentation of data (scored by two teachers who attended all presenta- tions). The course proved to be intensive and demanding for students, but with teacher's time and assistance, as well as their encouragement, the initial anxiety of students about the complexity of the practical work was transformed into very proud presentations on the last day and satisfaction with the creative work performed.

\section{The Third Year}

The third year's course, consisting of 25 hours (one week) of teaching, was devoted to mastering concepts and basic skills of evidencebased medicine (EBM). During the first day, students were introduced to five basic steps of EBM: 1) asking focused questions, 2) finding evidence, 3) critical appraisal, 4) making a decision, and 5) evaluating performance. During practicals of the first day, they used their knowledge from previous years to calculate numbers needed to treat (NNT) from results of published clinical trials, and interpret those NNTs in the context of provided confidence intervals. During the second day, the students practiced formulating questions using a PICO format (Patient and Problem, Intervention, Comparison, Outcome) from cases presented as brief clinical vignettes. The next day, they used PICO to create a search strategy for PubMed and identify relevant studies with different study designs. The third day was focused on critical appraisals of a randomized controlled trial (RCT) related to individual PICO question, followed by critical appraisal of a systematic review questions on the fourth day. Critical appraisal sheets were used for each practical work (37). Each practical task was graded and constituted $70 \%$ of the final course grade, with a brief knowledge test on $\mathrm{EBM}$ at the end of the course $(30 \%$ of the final grade). The vignettes for students were created based on existing systematic reviews in the Cochrane Collaboration Database of Systematic Reviews, to ensure that the stu- 
dents would be able to find and appraise the best available evidence for their clinical question. Students were very responsive to this course and found it most relevant and useful for their medical studies, particularly as a preparation for the clinical part of the curriculum.

\section{The Fourth Year}

The fourth year course ( 25 hours), unlike the courses of the first three years, was integrated with the clinical courses (internal medicine, neurology, and psychiatry) and structured as a "journal club" (38). Each week 3 student-hours were dedicated to a single type of study design and detailed analysis of a paper about a cross-sectional study, cohort study, case-control study, randomized controlled trial and systematic review. Topics were chosen either by the students themselves or their clinical mentors. Our goal was to offer the opportunity to the students to acquaint themselves with research performed by the clinicians working in the University Hospital Center, as well as with papers that physicians regarded highly relevant for their everyday practice. Each "journal club" was graded, and the final exam was a task similar to that of the previous year, yet instead of a vignette we provided, the students had to identify a clinical question about an actual patient they encountered on their clinical rotations. The English language of the presented articles did not pose a problem for the students, as all Croatian students start learning English as their first foreign language from their first year of primary schools. Although we believed that the course structured as a "journal club" would add valuable content to students' morning clinical training, it proved too time-consuming for the students, and students felt that it took away the time needed for studying for the clinical course exam.

\section{The Fifth Year}

The fifth year's block, consisting of 25 hours (one week) of teaching was devoted to developing a research plan for the graduation thesis that the students had to conduct during the sixth year. Our previous experience suggested that the key reason for unsuccessful research, especially in clinical medicine is poor or incomplete planning $(39,40)$. We developed a checklist with 21 items, with precise instructions on what the students had to include in their research plan that was formally submitted as the protocol for their diploma work. The checklist included defining outcome measures, calculating sample size needed, and listing of authors, with perceived contributions for each author according to ICMJE authorship criteria (41). Students either developed their own research projects and later found mentors or selected research projects already offered by School's teachers. The actual plan of research was returned up to 3 times to students, with detailed written instructions (using track changes in a word processor) of what should be corrected and/or completed. Most common students' mistakes and difficulties in formulating research plans are presented in Table 2. The final mark of the course was composed of points evaluated for each item on the research plan. Writing of the plan was very valuable for the students' sixth year diploma work, as the students became aware of all phases of research study, as well as the level of quality that would be expected from their final graduation tasks. It was our impression that it was on this level of science education that students sincerely and fully comprehended what research was, what its function was and why it was so strenuous and yet at the same time exciting and rewarding. 
Table 2 Teachers' experiences in supervising $5^{\text {th }}$ year medical students during their writing of research proposals for their MD theses at the University of Split School of Medicine

\begin{tabular}{|c|c|c|}
\hline Proposal item* & $\begin{array}{l}\text { What was expected from } \\
\text { students }\end{array}$ & $\begin{array}{l}\text { What students usually wrote in the first draft and how they } \\
\text { revised it }\end{array}$ \\
\hline Title & $\begin{array}{l}\text { Clear and concise indicative or } \\
\text { informative title }\end{array}$ & $\begin{array}{l}\text { Study design was usually not indicated; when it was added, } \\
\text { students appreciate the precision of the title and said that } \\
\text { seeing a clear title encouraged them for further work. }\end{array}$ \\
\hline $\begin{array}{l}\text { Scientific } \\
\text { background }\end{array}$ & $\begin{array}{l}\text { Short, focused description of } \\
\text { the research field and existing } \\
\text { evidence }\end{array}$ & $\begin{array}{l}\text { Students tended to write too long and very general } \\
\text { introductions. A lot of effort was needed to focus them on the } \\
\text { actual problem that would be covered by the thesis. }\end{array}$ \\
\hline Hypothesis & $\begin{array}{l}\text { Explicit, clear and brief } \\
\text { statement }\end{array}$ & $\begin{array}{l}\text { Students tended to have too many hypotheses, discussing those } \\
\text { hypotheses and primary objective of their research helped them } \\
\text { focus on one or two most important outcomes. }\end{array}$ \\
\hline $\begin{array}{l}\text { Originality of } \\
\text { research }\end{array}$ & $\begin{array}{l}\text { Brief explanation whether the } \\
\text { proposed research is original }\end{array}$ & $\begin{array}{l}\text { Student defended the originality of their work by stressing the } \\
\text { local relevance ("first in our country") and rarely planned to use } \\
\text { analytical study designs. }\end{array}$ \\
\hline Study design & $\begin{array}{l}\text { Rationale for study design } \\
\text { proposed }\end{array}$ & $\begin{array}{l}\text { This section was most often poorly written, and the most } \\
\text { common study design was a "retrospective study". Usually we } \\
\text { had to discuss the research question in great detail to arrive at } \\
\text { appropriate study design; this often lead to the revision of other } \\
\text { items. }\end{array}$ \\
\hline Sample & $\begin{array}{l}\text { Detailed definition of the study } \\
\text { sample, with inclusion and } \\
\text { exclusion criteria }\end{array}$ & $\begin{array}{l}\text { Most often these were already well explained in the first draft; } \\
\text { more problems were encountered with epidemiological studies, } \\
\text { where the population was often not clearly defined. }\end{array}$ \\
\hline $\begin{array}{l}\text { Sample size } \\
\text { calculation }\end{array}$ & $\begin{array}{l}\text { Calculation of the sample size, } \\
\text { using statistical software of } \\
\text { web-sites }\end{array}$ & $\begin{array}{l}\text { Students mostly came to the teacher for advice before } \\
\text { addressing this item. This task was very useful for them to clarify } \\
\text { study design, study groups and outcome measures, as well as to } \\
\text { review basic statistical concepts. }\end{array}$ \\
\hline $\begin{array}{l}\text { Subjects and } \\
\text { methods }\end{array}$ & $\begin{array}{l}\text { Concise description of the } \\
\text { subjects and methods }\end{array}$ & $\begin{array}{l}\text { Regularly well written. Students mostly needed to be reminded } \\
\text { to refer to literature or manufacturers when they described the } \\
\text { methods. }\end{array}$ \\
\hline $\begin{array}{l}\text { Primary outcome } \\
\text { measure }\end{array}$ & Clear description & $\begin{array}{l}\text { Regularly well written; sometimes students had to add } \\
\text { measuring units. }\end{array}$ \\
\hline $\begin{array}{l}\text { Secondary outcome } \\
\text { measures }\end{array}$ & Clear description & $\begin{array}{l}\text { Very often students listed too many secondary outcome } \\
\text { measures, and mentioned those they would not measure. } \\
\text { Discussion was often needed to clarify the difference between } \\
\text { primary and secondary outcome measures. }\end{array}$ \\
\hline $\begin{array}{l}\text { Potential sources } \\
\text { of bias and } \\
\text { confounding factors }\end{array}$ & List and explanation & $\begin{array}{l}\text { Very hard concept for students; this was the part of the proposal } \\
\text { that needed a lot of discussion and supervision. }\end{array}$ \\
\hline Statistics & $\begin{array}{l}\text { Description of the statistical } \\
\text { analysis and data presentation }\end{array}$ & $\begin{array}{l}\text { The statistical methods used are usually simple univariate } \\
\text { statistics. The discussion with students helped them revisit basic } \\
\text { statistical principles. }\end{array}$ \\
\hline Expected results & $\begin{array}{l}\text { Description of expected } \\
\text { results in view of the proposed } \\
\text { hypothesis and of the } \\
\text { importance of results }\end{array}$ & $\begin{array}{l}\text { This section was most often poorly written; students do not } \\
\text { have clear concept of what would be the concrete result of their } \\
\text { work. }\end{array}$ \\
\hline $\begin{array}{l}\text { Internal and } \\
\text { external validity }\end{array}$ & $\begin{array}{l}\text { Brief arguments for the validity } \\
\text { of the study }\end{array}$ & $\begin{array}{l}\text { External validity posed a special problem for students; it } \\
\text { appeared that they need more research experience and better } \\
\text { knowledge of the research field to address this issue. }\end{array}$ \\
\hline References & $\begin{array}{l}\text { According to the Vancouver } \\
\text { style }\end{array}$ & $\begin{array}{l}\text { This was the part of the proposal that tested students' eye for } \\
\text { detail and a good practice for them in making a technically well- } \\
\text { formatted report. }\end{array}$ \\
\hline
\end{tabular}


Table 2 (continued)

\begin{tabular}{|c|c|c|}
\hline Proposal item* & $\begin{array}{l}\text { What was expected from } \\
\text { students }\end{array}$ & $\begin{array}{l}\text { What students usually wrote in the first draft and how they } \\
\text { revised it }\end{array}$ \\
\hline Publication plan & $\begin{array}{l}\text { Decision on the first-choice } \\
\text { journal for the publication of } \\
\text { results, indicate the web-page } \\
\text { of the journal }\end{array}$ & $\begin{array}{l}\text { Students liked this part of their proposal and often studied } \\
\text { journals and their impact factors in detail. They also most often } \\
\text { aimed too high. }\end{array}$ \\
\hline Authorship & $\begin{array}{l}\text { Provisional list of authors } \\
\text { on the byline, according to } \\
\text { initial work division. Planned } \\
\text { contributions have to satisfy } \\
\text { ICMJE† criteria. }\end{array}$ & $\begin{array}{l}\text { This section provided the opportunity to discuss the difference } \\
\text { between a thesis and a research paper. Students felt strongly } \\
\text { about being the first authors inasmuch as they planed to make } \\
\text { the largest contribution to research and writing. }\end{array}$ \\
\hline Financing & $\begin{array}{l}\text { Plan for or existing sources of } \\
\text { funding }\end{array}$ & $\begin{array}{l}\text { Usually no funding was planned or was available. This item was } \\
\text { included to remind students about possible financial conflicts of } \\
\text { interest and the need for their declaration. }\end{array}$ \\
\hline Conflict of interest & $\begin{array}{l}\text { Description of possible } \\
\text { conflicts of interest }\end{array}$ & $\begin{array}{l}\text { Usually none declared. This item was always discussed with a } \\
\text { student, and they were asked to consult their mentors. }\end{array}$ \\
\hline Intervention & $\begin{array}{l}\text { Description of the intervention, } \\
\text { if planned }\end{array}$ & $\begin{array}{l}\text { Students rarely performed research involving testing of an } \\
\text { intervention. This is the reason for putting this item so far in the } \\
\text { proposal and making it optional. In rare instances of planned } \\
\text { intervention studies, students needed assistance in clarifying } \\
\text { the details about the intervention. }\end{array}$ \\
\hline Preliminary research & $\begin{array}{l}\text { Description of any pilot results, } \\
\text { if they exist }\end{array}$ & $\begin{array}{l}\text { Preliminary research was rarely performed by students. If they } \\
\text { did a pilot study, they needed assistance in describing the result. }\end{array}$ \\
\hline
\end{tabular}

*Teachers read the proposal 1-3 times, providing suggestions what and how to correct and complete all items. Students also came for consultations and discussions on items they found difficult to address. Teachers insisted on technical and language excellence of writing. tInternational Committee of Medical Journal Editors, www.ICMJE.org.

\section{The Sixth Year}

The sixth year was entirely devoted to the execution of research planned in the fifth year, including data collection, data analysis, interpretation and thesis writing. The final mark of the thesis was deduced from the sum of points the thesis was given for technical excellence (Supplementary table 2), average of points given by three members of the Graduation Thesis Defense Committee for the scientific quality of the thesis (Supplementary table 3), and average of points given by the three members of the Graduation Thesis Defense Committee for student's presentation and defense of the thesis (Supplementary table 4 ); $56 \%-65 \%$ points was sufficient (grade 2), 66\% - 75\% good (grade 3), $76 \%-85 \%$ very good (grade 4 ), and $\geq 86 \%$ points excellent (grade 5 ). The results of this year, i.e. the quality of the structure, content and style of the graduation theses surprised us. All students obtained, and de- served, excellent marks. We cannot assess how much this success was a product of our constant assistance to students, work of their individual mentors, clear-cut plans for research from the previous year's course, extensive instructions for thesis composition, detailed and transparent criteria of thesis evaluation and defense (Supplementary tables 2, 3 and 4), or of the maturation of students and their growing awareness that soon they will be headed to independent working positions. The experience was rewarding and highly appreciated by the students, their mentors and teachers at our Department, who provided methodological advice during the thesis work and writing. As in line with the University of Split regulations, the theses were made publicly available through the School's library webpage.

\section{Discussion}

As editors and educators we have found our work with students in teaching research 
skills and scientific communication more rewarding than working with journal authors, who were already fully formed when they started being interested in research and publications (42). By the time most health professionals come to doctoral programs, which are the usual points of intervention for capacity building in research in developing countries (43), individuals are already formed and usually anxious about numbers, statistics and study design (44).

Medical students initially shared those anxieties but overcame them more easily and learned to appreciate the gradual increase in their own understanding and applicability of medical science, which in the end culminated with feelings of satisfaction and pride in the quality of their own research and diploma theses. Our analysis of students' responses to the course (and its 6 parts as shown in Table 2) was based on our communication with students (which was abundant), analysis meetings of the Department's members, reactions of mentors, and of students and members of defense committees at and after the defenses of the theses. The lack of an objective and systematic analysis thus opens the possibility that our evaluation was either biased or attributable to low evaluation criteria; however due to our familiarity with the previous thesis works, we believe we have substantially increased the criteria and evaluated them objectively. As the graduation theses made in the School of Medicine in Split are published on the internet (http:// library.foi.hr $/ \mathrm{m} 3 / \mathrm{ksrez}$.asp? $\mathrm{B}=419 \& \mathrm{~N}=50$ \& $\mathrm{V}=\mathrm{FDI} \& \mathrm{~J}=\& \mathrm{~K}=\& \mathrm{O}=\& \mathrm{~S}=\& \mathrm{css}=\& \mathrm{dlib}=1 \&$ Upit=), those from years 2011 and 2012 are open to comparisons with those published before the new curriculum, as well as with those produced in other medical schools.

Finally, we truly feel there can be no good research for health if education for research does not come first (45). The research in biomedicine course, in all forms of knowledge and skills offered and required, empowers students of health professions to follow and practice principles of evidence-based medicine which no longer can be separated from everyday practice (42). Both searching for an answer to the question about a real patient and researching a novel intervention require careful definition of a question, identification and critical assessment of evidence and drawing relevant and objective conclusions. Teaching research needs to start earlier and be integrated with teaching practice. This is fully in line with the latest recommendations on basic medical education from the World Federation for Medical Education (Box 1).

Box 1. Recommendations of the World Federation for Medical Education (WFME) for science teaching in medical schools (Standards for basic medical education; The 2012 revision (ref. 20).

\subsection{SCIENTIFIC METHOD}

Basic standard:

The medical school must

- Throughout the curriculum teach

- The principles of scientific method, including analytical and critical thinking. (b 2.2.1)

- Medical research methods. (b 2.2.2)

- Evidence-based medicine. (B 2.2.3)

Quality development standard:

The medical school should

- In the curriculum include elements of original or advanced research. (Q 2.2.1)

Annotations:

- To teach the principles of scientific method, medical research methods and evidence-based medicine requires scientific competencies of teachers. This training would be a compulsory part of the curriculum and would include that medical students conduct or participate in minor research projects.

- Elements of original or advanced research would include obligatory or elective analytic and experimental studies, thereby fostering the ability to participate in the scientific development of medicine as professionals and colleagues. 
For those willing to try a similar course schedule, we would recommend having students write their research proposals on the fourth year, and having "journal clubs" on the fifth, to enable students to discuss papers directly related to their own research topics. Even for those students who later in their careers decide not to partake in their own or others' research, we believe critical thinking they obtain through science teaching will forever remain an invaluable tool. It is now our further goal to cultivate a climate within our School and University which would enable publications of all students' work started as diploma thesis as full papers in peer-reviewed journals, and we therefore encourage other institutions to start building and strengthening research capacity from the first year of university level of health education.

Authors' contributions: Conception and design: AM, MM; Acquisition, analysis, and interpretation of data: AM, MMal, DS, AJ, MM; Drafting the article: AM, DS, MM; Revising it critically for important intellectual content: AJ, MMal.

Conflict of interest: The authors declare that they have no conflict of interest.

\section{References}

1. Maclure M. Dr. Tom Chalmers, 1917-1995: The trials of a randomizer. CMAJ. 1996;155:757-60.

2. Pang T, Terry RF, The PLoS Medicine Editors. WHO/PLoS Collection "No Health Without Research": A call for papers. PLoS Med. 2011;8:e1001008.

3. Glasziou PP, Sawicki PT, Prasad K, Montori VM; International Society for Evidence-Based Health Care. Not a medical course, but a life course. Acad Med. 2011;86:e4.

4. Novak K, Mirić D, Jurin A, Vukojević K, Aljinović J, Carić A, et al. Awareness and use of evidencebased medicine databases and Cochrane $\mathrm{Li}^{-}$ brary among physicians in Croatia. Croat Med J. 2010;51:157-64.

5. Utrobičić A, Chaudhry N, Ghaffar A, Marušić A. Bridging knowledge translation gap in health in developing countries: visibility, impact and publishing standards in journals from the Eastern Mediterranean. BMC Med Res Methodol. 2012;12:66. doi: 10.1186/1471-2288-12-66.
6. Yamey G. Scaling up global health interventions: A proposed framework for success. PLoS Med. 2011;8:e1001049.

7. RemmeJHF, Adam T, Becerra-Posada F, D’Arcangues C, Devlin M, Gardner C, et al. Defining research to improve health systems. PLoS Med. 2010;7:e1001000. doi: 10.1371/journal.pmed.1001000.

8. Chan L, Kirsop B, Arunachalam S. Towards open and equitable access to research and knowledge for development. PLoS Med. 2011;8:e1001016.

9. Paraje G, Sadana R, Karam G. Public health. Increasing international gaps in health-related publications. Science. 2005;308:959-60.

10. Marušić A, Marušić M. Small scientific journals from small countries: breaking from a vicious circle of inadequacy. Croat Med J. 1999;40:508-14.

11. Marušić A, Marušić M. Can small journals provide leadership? Lancet. 2012;379:1361-3.

12. Mišak A, Marušić M, Marušić A. Manuscript editing as a way of teaching academic writing: experience from a small scientific journal. Journal of Second Language Writing. 2005;14:122-31.

13. Marušić $A$, Marušić $M$. Teaching students how to read and write science: a mandatory course on scientific research and communication in medicine. Acad Med. 2003;78:1235-9.

14. Hren D, Lukić IK, Marušić A, Vodopivec I, Vujaklija A, Hrabak M, et al. Teaching research methodology in medical schools: students' attitudes towards and knowledge about science. Med Educ. 2004;38:81-6.

15. Vujaklija A, Hren D, Sambunjak D, Vodopivec I, Ivaniš A, Marušić A, et al. Can teaching research methodology influence students' attitude toward science? Cohort study and nonrandomized trial in a single medical school. J Investig Med. 2010;58:282-6.

16. Burazeri G, Čivljak M, Ilakovac V, Janković S, Majica T, Nedera O, et al. Survey of attitudes and knowledge about science in medical students in Southeast Europe. BMJ. 2005;331:195-6.

17. Marušić M, Hren D, Roso V, Donev DM, Marušić A. Is mandatory training in research methodology associated with attitudes and knowledge about science in medicine? Survey of Croatian medical interns at license examination over eight years. Med Teach. 2010;32:348.

18. Directive 2005/36/EC of the European Parliament and of the Council of 7 September 2005 on the recognition of professional qualifications. Official Journal of the European Union. 2005;L 255:22142. [cited 2013 Feb 27]. Available from: http:// eurlex.europa.eu/LexUriServ/LexUriServ.do?uri= OJ:L:2005:255:0022:0142:EN:PDF. 
19. Republic of Croatia. Act on the Recognition of Foreign Educational Qualifications (Official Gazette, No. 158/03, 198/03, 138/06 and 45/11).

20. World Federation for Medical Education (WFME). Standards for basic medical education. The 2012 revision. [cited 2013 Feb 27]. Available from: http://www.wfme.org/news/generalnews/263-standards-for-basic-medical-education-the-2012-revision.

21. Grković I, Sapunar D, Marušić M. Ways to address the challenges of a modern medical curriculum: living academic medicine at the University of Split, School of Medicine. Acta Med Acad. 2012;41:7-17.

22. Committee on Assessing Integrity in Research Environments, National Research Council, Institute of Medicine. Integrity in scientific research. Creating an environment that promotes responsible conduct. Washington, D.C: The National Academies Press; 2002. p. 98-100. [cited 2013 Feb 27]. Available from: http://www.nap.edu/openbook. php?record_id $=10430$ \&page $=84$.

23. Wlodkowski R J. Enhancing adult motivation to learn: a comprehensive guide for teaching all adults. (rev. ed.). San Francisco: Jossey-Bass; 1999.

24. Karpicke JD, Blunt JR. Retrieval practice produces more learning than elaborative studying with concept mapping. Science. 2011;331:772-5.

25. Darkenwald G, Merriam S. Adult education: Foundations of practice. New York: Harper \& Row; 1982.

26. Dickenson G, Clark KM. Learning orientations and participation in self-education and continuing education. Adult Education. 1975;26:3-15.

27. Tight M. Key concepts in adult education and training. New York: Routledge Publishing; 1996.

28. Loucks-Horsley S, Hewson PW, Love N, Stiles KE. Designing professional development for teachers of science and mathematics education. Thousand Oaks, CA: Corwin Press; 1998.

29. Strike K, Posner G. A revisionist theory of conceptual change. In: Duschl R, Hamilton R, editors. Philosophy of science, cognitive psychology, and educational theory and practice. Albany, NY: State University of New York; 1992. p. 211-31.

30. Bruffee KA. Collaborative learning: Higher education, interdependence, and the authority of knowledge. Baltimore, MD: The Johns Hopkins University Press; 1993.

31. Even MJ. The adult learning process. Perspectives in Adult Learning and Development. 1981;1:13-9.

32. Merriam SB, Caffarella RS. Learning in Adulthood. San Francisco, CA: Jossey-Bass; 1999.
33. Parker LH, Rennie LJ. Equitable assessment strategies. In: Fraser B, Tobin KG, editors. International handbook of science education, Part 2. Dordrecht, The Netherlands: Kluwer Academic Publishers; 1998. p. 897-910.

34. Marušić $M$, editor. Principles of evidence-based medicine. 1st edition. Zagreb: Medicinska naklada; 2008.

35. Ferenczi E, Muirhead N. One Stop Doc Statistics and Epidemiology. Oxford: Oxford University Press; 2007.

36. Likić R, Dušek T, Horvat D. Analysis and prospects for curricular reform of medical schools in Southeast Europe. Med Educ. 2005;39:833-40.

37. Centre for Evidence Based Medicine, University of Oxford. Critical appraisal sheets. [cited 2013 Feb 27]. Available from: http://www.cebm.net/index.aspx?o=1913.

38. Deenadayalan Y, Grimmer-Somers K, Prior M, Kumar S. How to run an effective journal club: a systematic review. J Eval Clin Pract. 2008;14:898911.

39. Marušić M. Life of an editor. Zagreb: Croatian Medical Journal and Medicinska naklada; 2010.

40. Mišak A, Marušić M, Marušić A. Manuscript editing as a way of teaching academic writing: experience from a small scientific journal. Journal of Second Language Writing. 2005,14(2):122-31.

41. International Committee of Medical Journal Editors. Uniform Requirements for Manuscripts Submitted to Biomedical Journals: Ethical Considerations in the Conduct and Reporting of Research: Authorship and Contributorship. [updated 2010 Apr; cited 2013 Feb 27]. Available from: http:// www.icmje.org/ethical_lauthor.html.

42. Perrier L, Mrklas K, Shepperd S, Dobbins M, McKibbon KA, Straus SE. Interventions encouraging the use of systematic reviews in clinical decision-making: a systematic review. J Gen Intern Med. 2011;26:419-26.

43. Bates I, Phillips R, Martin-Peprah R, Kibiki G, Gaye O, Phiri K, et al. Assessing and strengthening African universities' capacity for doctoral programmes. PLoS Med. 2011;8(9):e1001068.

44. Lang T. Twenty statistical errors even you can find in biomedical research articles. Croat Med J. 2004;45:361-70.

45. Marušić A, Sambunjak D, Jerončić A, Malički M, Marušić M. No health research without education for research - experience from an integrated course in undergraduate medical curriculum. Med Teach. 2013;35:609. 
Supplementary table 1

Principles of adult learning and course development*

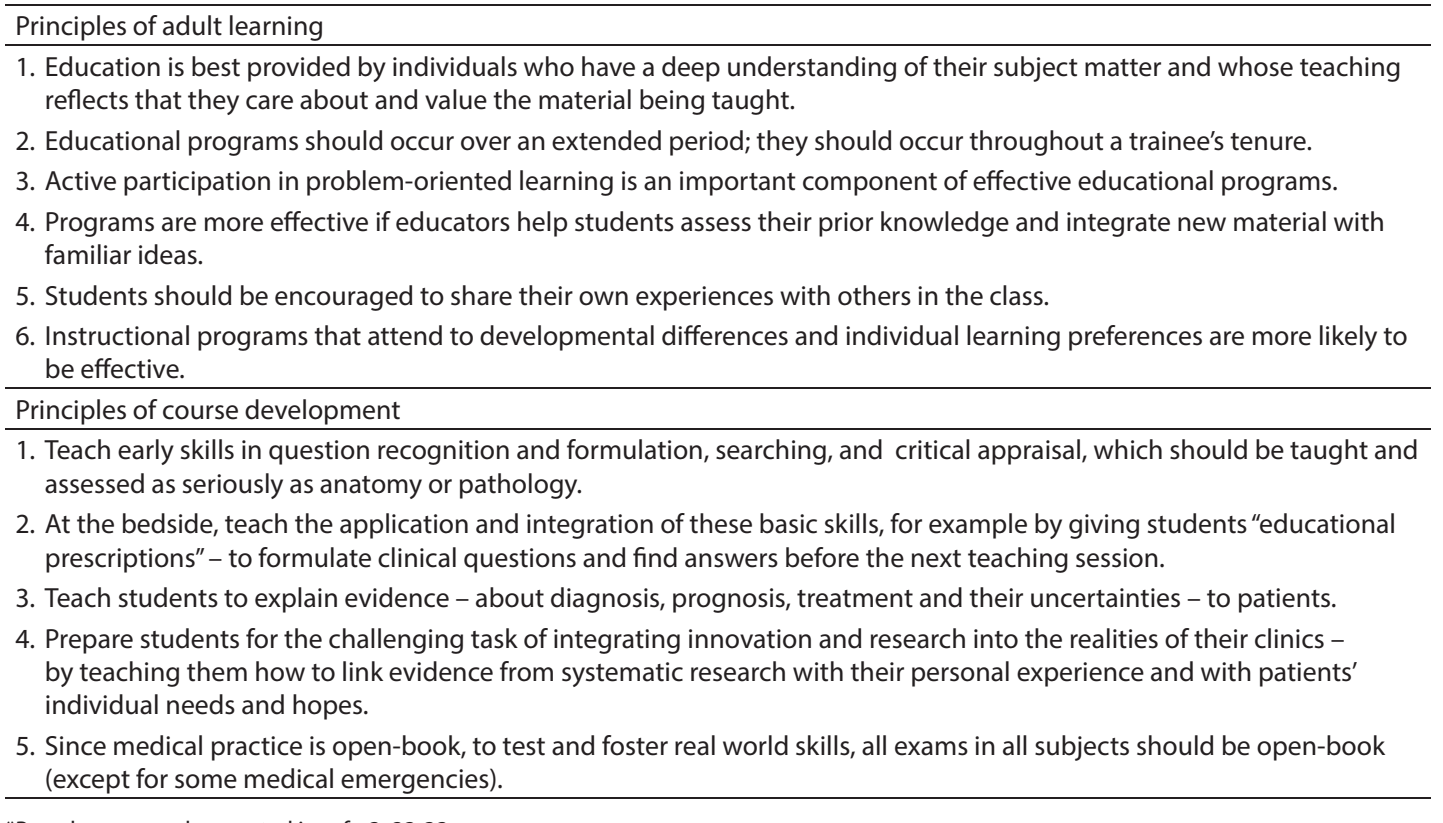

*Based on research reported in refs. 3, 23-33.

\section{Supplementary table 2}

Technical elements of student's graduation thesis evaluated by the teachers from the Department of Research in Biomedicine and Health

Thesis elements*

1. Technical presentation: Page breaks, indenting and line spacing, consistency of presentation through headings and subheadings.

2. Title: Clarity, congruence with hypothesis, indication of the type of study

3. Sample size calculation: Adequate description of sample size calculation, including formula details, data source, type of statistical test, study strength, $\mathrm{P}$ value and sample needed per group (if applicable).

4. Participants: Participants details, inclusion and exclusion criteria

5. Study groups: Study group(according to hypothesis), intervention and control group (if applicable)

6. Outcome measures: All outcome measures and their descriptors indicated (e.g. g/L, yes/no, etc.)

7. Confounding factors: Possible confounding factors listed, as well as their possible influence on the results

8. Ethical approval: Details of an approval by an ethical committee need to be listed, or the plan for its obtainment

9. Statistical analysis: All tests and programs used need to be listed

10. Language and style: Orthography, spelling, typing errors

11. Data presentation follows guidelines of the study used (e.g. STARD, STROBE, CONSORT)

12. Study flow diagram: Clarity, completeness, accuracy

13. Tables: Presentation, completeness, full title, clarity of the message, symbols used

14. Figures: Presentation, completeness of legend, clarity of the message

15. Referencing: ICMJE† style throughout the thesis

*Each element is given a score ranging from 0 till 2 ( 0 - poor, 1 - good, 2 - excellent). tInternational Committee of Medical Journal Editors, www.ICMJE.org. 


\section{Supplementary table 3}

Scientific elements of student's graduation thesis evaluated by three members of Graduation Thesis Defense Committee

Thesis elements*

1. Title of the thesis: Congruence with hypothesis, clarity, type of study given and number of subjects/patients

2. Theoretical background of the investigation (Introduction): Logical stream ("triangle"), clarity, relevance to the subject of research, logic of explanation for hypothesis/aim of the study, relevant citing

3. Hypothesis: Clarity, originality, importance

4. Appropriateness of the type of study: Are the type of the study and control group congruous with the hypothesis/aim of the study?

5. Sample: Did the author define a) population represented by the sample, b) type of sample, c) selection of subjects/ patients for the sample; laboratory animals or data sources?

6. Calculation of the minimal sample size: Is there clear-cut description of calculation, are all data included in the formula given, is the source/s of data for the formula given, which is the statistical test used, what are P-values, power of the study, and number of subjects per group (as calculated)?

7. Subjects/patients: Inclusion and exclusion criteria, experimental/test group (commensurate to the hypothesis), control group (commensurate to the experimental group)

8. 8. Outcome measures: Measuring units given for each listed outcome measure (e.g. g/L, yes/no, etc.), statistical measures specific for the type of the study (e.g. OR, RR, etc.)

9. Confounding variables and biases: Are the possible confounding variables and biases listed and how their influence on the results were controlled?

10. Statistics: All statistical measures of the outcome given, test applied for each analysis indicated, all $P$-values given

11. Flow chart of the study: Clarity, neatness, completeness, numbers in the boxes real and exact

12. Methods of data collection: Aources and methods of collection of all data listed, place of investigation, financing, appropriate ethical approval

13. Results - text: completeness and clarity of description of results, relevance of results to the hypothesis

14. Results - tables and figures: Each answers one question stemming from the deductive analysis of the hypothesis

15. Discussion: Logical flow („triangle"), soundness of explanation of scientific contribution, analysis of the weakness of the study

16. Conclusions: Clarity, originality, importance, foundation in the obtained results

17. Originality of research: With respect to the literature

18. Contribution to medical knowledge: At national and international level

19. Internal validity of research: Do the type of the study and outcome measures allow adequate testing of the hypothesis?

20. External validity of research: Generalizability of results discussed

*Each element is given a score ranging from 0 till 2 ( 0 - poor, 1 - good, 2 - excellent). 
Acta Medica Academica 2014;43:50-62

Supplementary table 4

Elements of student's presentation and defense of graduation thesis evaluated by three members of Graduation Thesis Defense Committee

\begin{tabular}{|c|c|c|c|}
\hline \multirow{2}{*}{ Element } & \multicolumn{3}{|c|}{ Points (from 0 - failure to 5 - excellent) } \\
\hline & First member & Second member & Third member \\
\hline
\end{tabular}

\section{Performance}

Quality of presentation slides

Clarity of presentation

Answers to questions of the Committee Member 1

Answers to questions of the Committee Member 2

Answers to questions of the Committee Member 3

Total 